\title{
Erratum to: Thermodynamic modeling of vapor-liquid equilibrium for binary polyethylene glycol/solvent solutions using cubic equations of state: optimization and comparison of CEOS models
}

\author{
Ebrahim Ahmadloo • Najmeh Sobhanifar
}

Published online: 17 May 2014

(C) Springer-Verlag Berlin Heidelberg 2014

Erratum to: Polym. Bull. (2014) 71:887-905

DOI 10.1007/s00289-014-1100-y

Unfortunately, in the original publication there is a typo in the affiliation of the co-author. The affiliation has been corrected in this erratum.

The online version of the original article can be found under doi:10.1007/s00289-014-1100-y.

E. Ahmadloo ( $\bowtie)$

Young Researchers and Elite Club, Darab Branch, Islamic Azad University, Darab, Iran e-mail: EbrahimAhmadloo@yahoo.com

N. Sobhanifar

Young Researchers and Elite Club, Shoushtar Branch, Islamic Azad University, Shoushtar, Iran e-mail: Sobhanifar.Najme@yahoo.com 